\title{
The "sweet-gorged Maw": Feeding and Physic in the Elizabethan Dramatic Life of Sir Thomas More
}

\author{
JOAN FITZPATRICK \\ Loughborough University, UK
}

La description que fait Anthony Munday de Sir Thomas More dans la pièce de théâtre du même nom est cohérente avec l'approche anti-catholique de Munday observable dans ses autres écrits, ainsi qu'avec son caractère fuyant. À travers toute cette pièce, des préoccupations au sujet de la sécurité nationale et du comportement des étrangers sont exprimés en termes de nourriture et d'alimentation, lesquelles marquent également la représentation de More. Alors que les biographes du martyr Thomas More le dépeignent comme un catholique modéré, voire ascétique, la pièce de Munday révèle plutôt un Thomas More davantage enclin aux plaisirs culinaires, avec le résultat qu'il y est présenté comme un hypocrite.

$\mathrm{T}$ he Elizabethan/Jacobean play Sir Thomas More presents a set of mysteries. Although clearly a collaborative endeavour, most of the play is in the hand of a writer whose anti-Catholic prejudices are well known: Anthony Munday. Critical reception of the play, such as it is for a work largely neglected by readers and performers, has tended to see the depiction of More as wholly positive. But why would Munday, apparently a committed Protestant, reinforce the Catholic view of More as a principled and attractive figure? Munday was a slippery customer and critics have argued that his anti-Catholic activities masked Catholic sympathies. This essay reconsiders the play's representation of More with a particular focus on the subtle criticisms of his character that emerge in the parts of it that Munday wrote, and argues that these criticisms make his involvement in the project less surprising. That is to say, read aright, Munday's contribution is consistent with the anti-Catholicism of his other writings. Also considered is early-modern dietary literature, specifically Andrew Boorde's Compendyous Regyment or a Dyetary of Helth and William Bullein's The Gouernment of Health. Both enormously influential texts, these dietaries offer the reader hitherto neglected insights into More's alleged appetite. A related issue is how decisions about performance, specifically the casting of the actor playing More, might help shape our view of the historical figure. 
The dominant textual tradition of twentieth-century New Bibliography has tended to take the habits of the best-known early-modern dramatist, Shakespeare, as typical of the period-even though we know that most playwriting was done in teams of between two and five dramatists and that Shakespeare was unusual in working on his own. This Shakespearianism has reinforced an inherited Romantic tradition of assuming that a literary/dramatic work is all of a piece; but the various hands in Sir Thomas More, although indicating a shared interest in particular themes, diverge in their depiction of More himself. I have considered elsewhere the scene apparently authored by Shakespeare that depicts events involving the riots of Londoners against resident foreigners on May Day 1517 (2.3) and argued that Shakespeare picked up on and repeated associations drawn between foreigners and food elsewhere in the play. ${ }^{1}$ Throughout Sir Thomas More, concerns about national security and the behaviour of foreigners are expressed in terms of food and feeding, and so too is the representation of More. By these means a less-than-positive picture of the man emerges. Reading the tensions within the play with a proper respect for how it was put together, we can see that the several artists who made it were (like the characters) not entirely pulling in the same direction.

Anthony Munday's reputation as Protestant zealot has been more often assumed than illustrated. As Donna B. Hamilton recently pointed out, Munday is "usually classified not only as a Protestant but as a 'rabid' Protestant or as 'rabidly' anti-Catholic or anti-papist-descriptors used by Celeste Turner [in Anthony Munday: An Elizabethan Man of Letters (1928)] and repeated routinely since." The assumption that Munday was a loyal Protestant is understandable given what we know about his life: he acted as a spy in the English College in Rome, testified for the English government in recusant trials, and worked as a pursuivant (a messenger or agent armed with a warrant to arrest). He was also employed by Elizabeth's chief torturer Richard Topcliffe: letters written by Topcliffe, amongst others, name Munday as delivering recusants and providing information on priests and other Catholics. Furthermore, there are records of Munday's testimony against specific individuals as well as attacks upon him by Catholics in print and letters. ${ }^{3}$ However, via a detailed study of his writings, Hamilton argued that Munday, though apparently a committed Protestant, actually promoted a dissident Catholic agenda. As Hamilton noted, suspicions that Munday was not what he seemed were previously raised by Turner herself, who revised her 1928 conclusion in a subsequent article, arguing that Munday's associations with the printers John Allde and John Charlewood indicate he went to the English College in Rome as a genuine convert to Catholicism, not as a spy, and was later "panicked into treachery," a position which, as Hamilton put 
it, "met opposition from some and has been given no consideration by many." assumption that Munday was a consistently loyal Protestant was also challenged by Thomas McCoog who thought him a "lapsed Catholic"s and Michael E. Williams who, like Turner, suggested that Munday entered the English College in all sincerity, only later turning informant. ${ }^{6}$ Tracey Hill described Munday as "a remarkable admixture of the omnipresent and the elusive" but her opinion that "one of the most intriguing and consistent features of his literary work-especially his prose ... is its directness" " is less convincing. Hamilton's characterization of Munday seems more in keeping with the man and his work: she described him as "a skilful equivocator and casuist," a man engaged in "rhetorical indirection" whose writings admit more than one reading. ${ }^{8}$ Munday's characterization of More adds to the impression of Munday as a complex figure, since his apparent admiration of the Catholic martyr is tempered by subtle but distinct criticism.

The only early-modern textual witness to the play Sir Thomas More is British Library manuscript Harley 7368, in several hands, and comprising 22 sheets. The bulk of the play is in a single hand that W.W. Greg designated "S," meaning scribe, and later realized was the handwriting of Anthony Munday. ${ }^{9}$ This block of main writing may also include contributions from Henry Chettle and Thomas Dekker, but since Munday was a successful writer it is no longer generally supposed that he was acting here merely as a copyist, and we may reasonably assign to him authorial agency in respect of Hand $S$. The front of the first sheet contains a provisional licence from Edmund Tilney, the state censor, requiring alterations before public performance. These "additions," that expand upon or rewrite scenes in the main body of the play, were apparently provided by Chettle and Dekker as well as Thomas Heywood and William Shakespeare. The "additions" might represent changes to the play made after Tilney's objections were known, but in some ways the changes (such as the rewriting of the scene in which More quells the rioters) only make worse the matters that Tilney objected to. Shakespeare's alleged contribution is a scene in his own handwriting ("Hand D") and a speech for More in C's handwriting, and these have undoubtedly encouraged recent interest in the play. The play was part of the Royal Shakespeare Company's “Gunpowder” season in 2005 (billed as being by "Anthony Munday, William Shakespeare and others") and an Arden Shakespeare edition of the play is being prepared by John Jowett. The theory that Shakespeare might have been a secret Catholic, put forward by E. A. J. Honigmann, ${ }^{10}$ amongst others, would explain why he was interested in contributing to a play about More, but Munday's contribution is puzzling unless we consider that Munday was indeed a Catholic or that an unflattering depiction of More is apparent in the play. 
In the scene thought to be in Shakespeare's hand, More admonishes the rioting Londoners for their lack of sympathy toward the resident foreigners:

\section{MORE}

Grant them removed, and grant that this your noise

Hath chid down all the majesty of England.

Imagine that you see the wretched strangers,

Their babies at their backs, with their poor luggage

Plodding to th' ports and coasts for transportation,

And that you sit as kings in your desires,

Authority quite silenced by your brawl,

And you in ruff of your opinions clothed:

What had you got? I'll tell you: you had taught

How insolence and strong hand should prevail,

How order should be quelled, and by this pattern

Not one of you should live an aged man,

For other ruffians, as their fancies wrought,

With selfsame hand, self reasons and self right

Would shark on you, and men like ravenous fishes

Would feed on one another.

$(2.3 .78-93)^{11}$

That More should refer to men feeding on one another is pertinent since earlier in the scene and elsewhere in the play the Londoners objected to the excessive appetites of foreigners: "[LINCOLN] they eat more in our country than they do in their own” (2.3.7-8). Honigmann read this speech as Shakespeare's "most moving plea in defence of Strangers ... [which] has a bearing on our interpretation of Othello, Shylock and others - and being so unmistakably sympathetic to Sir Thomas ... the 'Three pages' [those apparently in Shakespeare's hand] prove that Shakespeare was as open-minded about religion as about foreigners." Honigmann further asserted, "In short, whether or not the play was ever performed, the writing of the Three Pages was an act of considerable courage." 12

Less courageous perhaps is More's very next speech urging obedience to the king:

MORE What do you then,

Rising 'gainst him that God Himself installs

But rise 'gainst God? What do you to your souls

In doing this, $\mathrm{O}$ desperate as you are?

Wash your foul minds with tears, and those same hands

That you like rebels lift against the peace,

Lift up for peace, and your unreverent knees 
Make them your feet. To kneel to be forgiven

Is safer wars than ever you can make

Whose discipline is riot.

$(2.3 .112-121)$

As Honigmann noted, there is distinct dramatic irony (at least, retrospectively) in More insisting upon obedience to the monarch since, as anyone who knew the story anticipated, More will later refuse to accept the Oath of Supremacy. But Honigmann is right that Shakespeare is apparently emphasizing the difficulty of living according to "simple platitudes" rather than suggesting hypocrisy on More's part; he "appears to speak in good faith." ${ }^{13}$ Yet, this view of More as a sincere man living in difficult times is less evident in those parts of the play in Munday's hand. Before considering Munday's depiction of More, it will be useful to glance at those sections of the play where references to food and feeding also feature: those in Hand C, identified by Greg as a scribe ${ }^{14}$ and by Vittorio Gabrieli and Giorgio Melchiori as "a copyist, or more precisely a professional book-keeper" who "edited the revised manuscript for the stage, transforming it into a promptbook." ${ }^{15}$

Apart from the riot-quelling scene in Shakespeare's hand, there is a soliloquy at the beginning of Act 3 that seems, on stylistic evidence, to be Shakespeare's composition, ${ }^{16}$ albeit copied out by Hand C. More reflects on his promotion to Lord High Chancellor of England, attributing his good fortune to God and worrying that

these things,

Not physicked by respect, might turn our blood

To much corruption. But More, the more thou hast, Either of honour, office, wealth and calling,

Which might accite thee to embrace and hug them, The more do thou in serpents' natures think them, Fear their gay skins with thought of their sharp state,

And let this be thy maxim: to be great

Is, when the thread of hazard is once spun,

A bottom great wound up, greatly undone.

$(3.1 .12-21)$

More is characterized here as ascetic, using specifically dietary terms: position and wealth must be "physicked," that is purged, by respect. Dietary literature from the early-modern period made much of purging the body so as to maintain physical and mental health. Andrew Boorde identified particular herbs, as well as other foods, that would "purge melancholy" and William Bullein cited ancient medical authorities when praising the practice: "For Hippocrates sayeth, without doubt it is needfull to purge the superfluitie of the bodie."17 Obedience, respect for author- 
ity, and harmonious social order are further imaged in terms of feeding in More's encounter with Falkner, the long-haired ruffian who "hath set half the city in an uproar" (3.1.56). When Falkner announces to More "I knew I should to the pot" he compares his ruination to being cut in pieces like meat (OED pot n. 1), thereby echoing the cannibalistic metaphor used earlier by More who warned that "men like ravenous fishes / Would feed on one another" (2.3.92-93). More's play on "pot" ("Thou has been there it seems too late already," 3.1.90) reinforces his asceticism by making it clear that he disapproves of Falkner's obviously drunken state and the point is made by emphasizing More's punning wit. ${ }^{18}$ In the play More is apparently well known for his generous hospitality: he is said by Doll to keep "a plentiful shrievalty" (2.3.47), the mayor of London, his wife and her train come "to feast" with him (3.2.4), and he himself refers to being "patron of those days" (4.4.85). Yet his generosity is tempered by careful management: Doll describes him as a "good housekeeper" (2.3.63) and the Porter proclaims: "Nay, and ye bate him his due of his housekeeping, hang ye all. Ye have many lord chancellors comes in debt at the year's end, and for very housekeeping!" (5.2.15-17). ${ }^{19}$ The sparseness of More's table is emphasized upon the arrival of Erasmus to whom More announces:

\section{MORE}

My lord, I make you master of my house;

We'll banquet here with fresh and staid delights,

The muses' music here shall cheer our sprites;

The cates must be but mean where scholars sit,

For th'are made all with courses of neat wit.

(3.1.210-214)

More apparently feeds others generously, but he is not profligate and is especially keen to emphasize the intellectual nourishment that should suffice the scholar. But his focus on mean "cates" is also practical: that intellectuals could not digest certain foods as easily as those engaged in manual labour is repeatedly asserted in the early-modern dietaries. For example, Thomas Cogan warns that bacon "is in no wise commended as wholesome, especially for students, or such as have feeble stomackes. But for laboring men it is convenient ...” ${ }^{20}$ So too William Bullein claims that "Bacon is verie hard of digestion, and much discommended, and is hurtfull ... [suitable] Onelie vnto a hote cholericke labouring bodie”; and Phillip Moore, that "Bacon made of olde swyne ... [is] eiuil for idle people but holsome for them that labour."21

More's reputation as a generous, yet ascetic, man is evident in one of the play's main sources, Nicholas Harpsfield's sympathetic biography based on notes from 
More's son-in-law William Roper (who later wrote his own biography of More). It is also apparent from More's own autobiographical writings, official records, continental accounts of More's trial and death, and Erasmus's letters. ${ }^{22}$ The following statement is fairly typical: "Neither was there euer any man (woorthy to be relieued) that sought reliefe and helpe at his hande, that went not from him merie and cheerfull. For he was (as a man may say) the publique patrone of all the poore ...". ${ }^{23}$ More is reported as having encouraged his children "to take vertue and learning for their meate, and playe for their [sauce]"24 and as personally disdaining worldly pleasures:

He was sometime for godly purpose desirous to be solitarie, and to sequester him selfe from worldly company.... to occupye himselfe in prayer and studie together ... spending his time onely in deuout prayers and spirituall exercises.... so vsed he another rare and singular kinde of almes of his owne body, as to punish the same with whippes, the cordes knotted. And albeit by reason he would not be noted of singularitie, he conformed himself outwardly to other men in his apparell, according to his state and vocation, yet howe litel he inwardly esteemed such vanities, it well appered by the shirt of heare that he ware secretly next his body; whereof no person was priuie but his daughter onely, mistris Margarete Roper.... ${ }^{25}$

Harpsfield further reports that More was physically healthy, becoming sick only "a litle before he gaue ouer the office of the Lorde Chauncellour, and especially afterwarde, when he was shutt vp in the towre," and comments on his diet:

Being a yonge man, he vsed and delighted much in drinking of water. He vsed very small ale, and as for wine, he did but sippe of it onely for companies sake and pledging of his frendes. He more delighted to feede vpon biefe, salte meates and course breade, and that very well leavened, then vpon fine meates and breade. He loued very well milke and fruit and especially egges. ${ }^{26}$

While dietary authors generally preferred wine to ale or beer, some praised ale's health-giving properties. For example, Andrew Boorde argued that "Ale for an englysh man is a natural drynke" 27 and William Bullein, that although it was harmful to drink wine when hungry, drinking ale and beer on an empty stomach "dooeth good" (Bullein 1595, 77). Too much fruit was denounced in the early-modern dietaries, which also warned against inactive people eating too much beef. Yet Harpsfield does not claim that More ate too much of anything; indeed, the overwhelming impression given by Harpsfield is not of a man inclined toward dainties or expensive fare, but rather of one who consumes the food and drink of common English people. ${ }^{28}$

We have seen that although Shakespeare depicts More preaching obedience to the king yet later proving disobedient himself, his More nonetheless presents a 
largely sympathetic figure. Like Shakespeare, the writer of the material in Hand C also characterizes More as a generous host and a disciplined ascetic. In both cases, the tension between conflicting behaviours generates a complex character, not outright contradiction. With Munday's writing, however, things are considerably less straightforward. For example, upon the visit of the Lord and Lady Mayoress, More is apparently hospitable when he urges his servants "See that your lights be in a readiness, / The banquet shall be here" and admonishes his wife "God's me, madam, / Leave my lady mayoress? Both of us from the board? / And my son Roper too? What may our guests think?” (3.2.38-41). Here, More's concern for the welfare of others is emphasized, but so too is the impression of a man excessively concerned with reputation. In this respect, More is similar to Shakespeare's Coriolanus, whose need for success in battle Janet Adelman related to his lack of maternal nourishment: "The rigid masculinity that Coriolanus finds in war becomes a defense against acknowledgment of his neediness.... His body becomes his armor ... he himself becomes a weapon." ${ }^{29}$ It is not quite lack of nourishment, maternal or otherwise, that ails More and, for him, it is the words he will leave behind rather than military abilities that matter but, as will become clear, More and Coriolanus share a specific attitude to appetite. Harpsfield defended More against the accusation made by "his aduersaries and euill willers" that he was "against his will thrust out of the Chauncellourshipp." ${ }^{\circ}$ More sought to defend his posthumous reputation by composing the epitaph that would appear on his sepulchre. Harpsfield claimed that More's enemies then "beganne, causeless, to prattle and talke against his saide Epitaphe as very vaineglorious. Against whose false slaunderous calumnies, the open tried truth of all his vertuous innocent life doth defende it selfe ...". ${ }^{11} \mathrm{Half}$ a century later, Munday's writing in the play might be a revival of the old accusation that More was preoccupied by what others thought about him, and it is in references to his own feeding when compared with the feeding of others that criticism of More is most apparent.

All of acts 4 and 5 are in the hand of Anthony Munday. In 4.1, set in the Privy Council chamber and apparently around the council table, More observes that:

Upon this little board is daily scanned

The health and preservation of the land.

We the physicians that effect this good,

Now by choice diet, anon by letting blood.

Our toil and careful watching brings the king

In league with slumbers, to which peace doth sing.

$(4.1 .15-20)$ 
More makes the traditional comparison between the country and the body, the effective politician and the careful physician, that is familiarly at work in, for example, William Bullein's dietary The Gouernment of Health ${ }^{32}$ and that was claimed by E. M. W. Tillyard to be a commonplace of early-modern thought. ${ }^{33}$ Yet by focussing on the cares taken by the privy council, More is implicitly critical of the absent king. It is doubtless relevant that this comment is made shortly before More refuses to sign the articles that Henry sends to the council via Sir Thomas Palmer (4.1.69-72). The dramatic effect is to imply monarchic aloofness, but the imagery of the council's careful dieting of the body politic and of a king "In league with slumbers" also suggests that the court is dangerously self-indulgent. More goes on to strengthen this implication by joking with the nobles: "What ails your lordships look so melancholy? / O, I know you live in court, and the court diet / Is only friend to physic" (4.2.111-113).

Such generalized comment on the court becomes specific in More's conversation with Roper. In response to Roper's reflection on the transitoriness of human existence- "in this general court of short-lived pleasure, / The world, creation is the ample food / That is digested in the maw of time" (4.4.41-44)-More launches a specific attack upon the gluttonous prince:

MORE

Nature provides content for the base mind:

Under the whip, the burden and the toil

Their low-wrought bodies drudge in patience;

As for the prince, in all his sweet-gorged maw

And his rank flesh that sinfully renews

The noon's excess in the night's dangerous surfeits;

What means or misery from our birth doth flow

Nature entitles to us, that we owe. (4.4.70-77)

The central character's name allowed for puns on "more," in the sense of plenty, that deflect some of the force of this attack from Henry, thus turning it upon its maker. However, the target is clear from implicit reference to his huge appetite - the king was a notoriously immoderate feeder ${ }^{34}$ - and by this speech More implies that he avoids such excesses.

After More has resigned from the office of Lord Chancellor he jokes with his wife:

MORE

I have changed my life.

Am I not leaner than I was before?

The fat has gone: my title's only More.

Contented with one style, I'll live at rest: 
They that have many names are not still best.

I have resigned mine office: countst me not wise?

(4.2.69-74)

When an officer comes to arrest More, he again refers to his own eating habits, making the by now familiar swipe at courtly pleasures:

MORE

Give me thy hand, good fellow, smooth thy face:

The diet that thou drinkst is spiced with mace,

And I could ne'er abide it: 'twill not disgest,

'Twill lie too heavy, man, on my weak breast.

$(4 \cdot 4 \cdot 137-140)$

More presents himself as a moderate, even ascetic, man. Like Coriolanus-who denounces the hungry citizens as the very foodstuff they desire: "scraps", "musty superfluity" (1.1.220; 223), "noisome, musty chaff" (5.1.26) - More is disgusted by the appetite of others. For Coriolanus, subjectivity is located in the mind, heroism proceeds from the intellect, and the body is merely the means by which to achieve heroic stature. As Stanley Cavell put it, "what he incessantly hungers for is ... not to hunger, and not to desire, that is, not to be mortal"35; Coriolanus cannot deny his body's need for food despite his disgust at the ordinariness of feeding. Being human, Coriolanus must eat even if this necessary activity appears fraught with irritation for him: Menenius twice refers to his bad temper before dining (5.1.50; 5.2.34-35). Coriolanus's mother, Volumnia, made livid by her son's banishment, similarly exhibits a desire to abstain from food and immerse herself in mental activities: "Anger's my meat, I sup upon myself, / And so shall starve with feeding" (4.2.53-54). What emerges in the Roman play is an anxiety about food and feeding in general, coupled with a desire toward self-harm. Like Coriolanus, More is disgusted by appetite, yet More's claims to observe a spare diet himself prove retrospectively ironic when in 5.3 we learn that he has "gravel" in his urine. The gravel indicates that More has what was termed "the stone," that is, a stone in the kidney, urinary bladder, or gall-bladder (OED stone $n$. 10). Asked by his servant whether the urine should be taken to the doctor for examination, More presents a stream of gallows humour that will persist until the last moment of the play:

MORE

No, save thy labour, we'll cozen him of a fee.

Thou shalt see me take a dram tomorrow morning,

Shall cure the stone I warrant, doubt it not.

(5.3.28-30) 
The joke is repeated to Surrey in the next scene: "I come hither only to be let blood: my doctor here tells me it is good for the headache" (5.4.83-84). We might argue that the audience is supposed to find this humour endearing-here is a man who will "keep his chin up" in his darkest hour-although conceivably it is meant to go so far as to be annoying: here is a man who misjudges what is expected of him and others in difficult situations. In apparent contradiction are the references to More's careful feeding and the representation of his real physical condition and his jokes about it.

In Holinshed's Chronicles, More's persistent joking is described as inappropriate and irritating:

I cannot tell (saith master Hall) whether I should call him a foolish wise man, or a wise foolish man, for vndoutedlie he beside his learning, had a great wit, but it was so mingled with taunting and mocking, that it seemed to them that best knew him, that hée thought nothing to be well spoken except he had ministred some mocke in the communication. ${ }^{36}$

Harpsfield reported an exasperated Lady More who questioned her husband why "so wise a man, will now so play the foole to lye here in this close, filthy prison, and be content thus to be shutt vp amonge mise and rattes; when you might be abrode at your libertie," and responded to More's flippant reply with "Bone Deus, Bone Deus, man, will this gere neuer be lefte?"37 Lady More was denounced by Harpsfield: "And thus, loe, though Eve supplanted and ouerthrewe by her pleasant persuasions her husbande, our first father, Adam, in Paradise, yet could not this woman any thing infringe or breake the constant settled good purposes of this woorthy man, her husbande ..." ${ }^{8}$ But one wonders whether she has a point: might not the humour found irritating by contemporary commentators and More's own wife also jar with audience members watching Munday's play?

Munday's writing, like the writing in Hand C, presents More in an apparently positive light that on closer inspection shows a subtle undermining of the Catholic martyr. A self-proclaimed ascetic, More, who is critical of the king's excessive feeding, nonetheless refers to " $[t]$ he fat" that has gone from his own body (4.2.71), and we might choose to understand this as a kind of thin-man's irony even though the theatrical technology of prosthetic padding that could be removed for the later scenes was readily available. However, the balance tips strongly away from such irony and towards self-misrepresentation once it is revealed that More has gravel in his water. This condition was commonly believed to be the consequence of a injudicious diet, even gluttony. William Bullein stated that 
Among all mortall diseases, the stone is the greatest, a preuenter of time, a deformer of man, and the chiefe weakner of the body, and a grieuous enemie to the common wealth. Howe manie noble men and woorshipfull personages hath it slaine in this Realme: manie one, which commeth of hote wines, spices, long banquets, repletions, fulnesse, costifenesse, warme kéeping of the backe, salt meates, \&c. The remedie whereof is, in all poyntes contrarie to these causes, small wines, temperate béere or ale, no spices, but wholsome hearbs, as Time, Parcely, Saxifrage, \&c. Light meales, most chiefly the supper, no baked, nor rosted thing, but onely sodden meates, and oftentimes to relaxe the bellie with Cassia Fistula, newe drawne from the Cane, with sugar, and to eschew salt meates, and not to kéepe the backe warme: the stone is often found in yong children, which commeth of the parents, and oftentimes in old folke. Which stones bee ingendred as I haue saide: besides milke, fruites, hearbes, saltfish and flesh, hard cheese, \&c. 39

Andrew Boorde warned sufferers to abstain from consuming ale, beer, red wine, red herring, and salty fish and meats, ${ }^{40}$ many of which are the very foods Harpsfield specifically referred to More enjoying. This advice comes immediately after advice on the correct diet for curing gout, and indeed the ailments were (rightly) connected in the minds of the early moderns: we now know that they are caused by high levels of uric acid in the urine (the stone) or the blood (gout). Those familiar with Edmund Spenser's character of Avarice (The Faerie Queene 1.4.27-29), Shakespeare's Falstaff, and indeed the life of King Henry ${ }^{41}$ would have associated gout with excessive eating and drinking. Moreover, although his popular association with the joy of gluttony was entirely unfounded, the Greek philosopher Epicurus (341-270 BCE) was known to have died from a stone in his bladder. ${ }^{42}$

Although More's biographer Harpsfield mentioned More's affliction, Roper did not and nor did another apparent source for Sir Thomas More, John Harington's The Metamorphosis of Ajax. Harpsfield learnt of the ailment from More's correspondence and his report of it is entirely sympathetic:

After the making of which Statute, the world beganne to waxe more straite and rough toward Sir Thomas More and suche other as stoode against the kinges newe Supremacie. And as besyde his old disease of his brest, he was now greeued in the reynes by reason of grauell and stone, and with the crampe that diuers nightes gryped his legges, so dayly more and more there grewe toward him many other great causes of griefe and sorowes; which all he did moderate and temper with patient and spirituall consolation and comfort to heauenward. 43

Harpsfield referred explicitly to More's modest diet briefly, and only in passing, but Munday chose to have More repeatedly express his dislike of excessive feeding, 
which could only have the effect of making him seem like a hypocrite once the self-induced condition is revealed.

THE RECENT STAGING of Sir Thomas More by the Royal Shakespeare Company under Robert Delamere's direction is part of a rehabilitation that has included its being added to the second edition of Oxford University Press's William Shakespeare: The Complete Works. ${ }^{44}$ The decision to treat it as a fully-fledged play deserving of full editorial treatment (the previous edition printed only the bits by Shakespeare) means that it will receive more attention that hitherto. However, the Royal Shakespeare Company production means that, most peculiarly, more people will have seen the play than read it. This reverses the usual situation with Shakespeare and makes him rather like his contemporaries, and indeed most dramatists generally, in having more spectators than readers. Yet this also makes the recent Royal Shakespeare Company production especially important since it constitutes an important and sustained critical engagement with the text.

In the production there was little sense that More is anything but a sympathetic character. James Wood has rightly argued that as a character in popular biographies, Thomas More has been over-sentimentalized:

\footnotetext{
Most absurdly, because of Robert Bolt's screenplay, this barrister of Catholic repression is widely envisioned as modernity's diapason: the clear, strong note of individual conscience, the note of the self, sounding against the authoritarian intolerance of the Early Modern state. Thomas More died in defense of an authoritarian intolerance much more powerful than a mere king's, however, for he died believing in God and in the authority of the pope and the Catholic Church. As Lord Chancellor, he had imprisoned and interrogated Lutherans, sometimes in his own house, and sent six reformers to be burned at the stake, and he had not done this just so that he might die for slender modern scruple, for anything as naked as the naked self. This drained, contemporary view of More, which admires not what he believed but how he believed — his "certainty," only—is thinly secular, and represents nothing more than the retired religious yearning of a nonreligious age. 45
}

A selective interpretation of the historical figure is also apparent in Delamere's production, demonstrating that the sentimentality detected by Wood has perhaps encouraged the theatre practitioners to overlook the subtle criticisms evident in Munday's depiction of More. The irony with which Munday interrogates More's sincerity is passed over in favour of an entirely positive view of More. Crucially, the actor cast as More (Nigel Cooke) is exceptionally thin; when Cooke removed his shirt in the scene leading up to More's execution, his startling physique was a 
dominant presence. Cooke is obviously fit and healthy but his body indicates a man not given to culinary indulgence. This was also true of the markedly gaunt Paul Scofield cast as More in the 1966 film A Man for all Seasons. ${ }^{46}$ Holbein's famous portrait of More presents us with a more substantial figure. If, as suggested by Turner and Hamilton, ${ }^{47}$ Anthony Munday was the "A. M." indicated as the translator of Oswald Gabelkover's The Boock of Physicke, a dietary in which particular foods are suggested for the treatment of common ailments including the stone, ${ }^{48}$ it is entirely possible that Munday's knowledge of food, feeding, and physic also informed his depiction of More. I do not wish to suggest that Munday presents an unequivocally negative picture of More but merely to note that, in much the same way that Hamilton and others have reconsidered Munday as necessarily Protestant, we might want to pause before reading Munday's More as falling entirely within the tradition of other, sympathetic biographies. It would be highly characteristic of Munday, termed "a skilful equivocator and casuist" by Hamilton, ${ }^{49}$ to have fun playing with his audiences' expectations and perceptions of his subject.

Ultimately, Munday's religious views are uncertain, as are the conditions and indeed the precise vectors of the collaborative authorship. However, we can draw together congruent aspects of these uncertainties, for when dealing with a play by multiple authors we should factor into our considerations an acceptance that the various writers might well have had different conceptions of the characters they created and of the story that they set out to tell. In Sir Thomas More, it seems, we can read these variations in the different characterizations by different writers. Moreover, if as Scott McMillin thinks, the play was first written in the early 1590s, then shelved as unplayable, and picked up again in the first years of the seventeenth century, ${ }^{5 \circ}$ we have here palimpsest of differing views of More recorded over a fairly long period of time. But coming into sharp relief is Munday's More: hospitable but excessively concerned with reputation, a man critical of courtly indulgence, specifically that of the monarch, but who himself suffers from an ailment commonly attributed to gluttony. The alert playgoer, especially one informed by dietary literature, would thus doubt the common characterisation of More as self-denying and, rather, perceive a man secretly given to culinary pleasure. 


\section{Notes}

1. Joan Fitzpatrick, "Food and Foreignness in Sir Thomas More," Early Theatre 7 (2004), pp. 33-40.

2. Donna B. Hamilton, Anthony Munday and the Catholics, 1560-1633 (Aldershot: Ashgate, 2005), p. xvi.

3. Hamilton, pp.xx-xxii.

4. Hamilton, p. xvi; Celeste Turner Wright, "Young Anthony Munday again," Studies in Philology 56 (1959), pp. 155-57.

5. Thomas M. McCoog, “The Flower of Oxford': The Role of Edmund Campion in Early Recusant Polemics," Sixteenth Century Journal 24 (1993), p. 900.

6. Michael E. Williams, The Venerable English College, Rome: A History, 1579-1979 (London: Associated Catholic Publications, 1979), p. 12.

7. Tracey Hill, Anthony Munday and Civic Culture (Manchester: Manchester University Press, 2004), pp. 4-5.

8. Hamilton, p. xvii.

9. W. W. Greg, ed., The Book of Sir Thomas More, Malone Society Reprints (Oxford: Oxford University Press, 1961), pp. xxxiv-xxxv.

10. E. A. J. Honigmann, Shakespeare: The "Lost Years," 2nd edn (Manchester: Manchester University Press, 1998).

11. All quotations of the play are from Anthony Munday, Sir Thomas More (Revised by Henry Chettle, Thomas Dekker, Thomas Heywood and William Shakespeare), ed. Vittorio Gabrieli and Giorgio Melchiori, The Revels Plays (Manchester: Manchester University Press, 1990).

12. E. A. J. Honigmann, "Shakespeare, Sir Thomas More and Asylum Seekers," Shakespeare Survey 57: Macbeth and Its Afterlife (2004), p. 226. The same view on Shakespeare's open-mindedness about foreigners, in relation to the ritual of mumming, was put forward by Richard Wilson in "Making Men of Monsters: Shakespeare in the Company of Strangers," Shakespeare 1 (2005) pp. 8-28.

13. Honigmann, "Shakespeare, Sir Thomas More and Asylum Seekers," p. 231.

14. W. W. Greg, ed., The Book of Sir Thomas More, Malone Society Reprints (Oxford: Malone Society, 1911), p. ix.

15. Munday, pp. 23-24.

16. Munday, p. 120.

17. Andrew Boorde, Compendyous Regyment or a Dyetary of Helth, STC 3380 (London: Wyllyam Powell, 1547), $\mathrm{H}_{3} \mathrm{r}$; William Bullein, The Gouernment of Health: a Treatise ... for the Especiall Good and Healthfull Preseruation of Mans Bodie from All Noysome Diseases, Proceeding By the Excesse of Euill Diet, and Other Infirmities of Nature: Full of Excellent Medicines, and Wise Counsels, for Conseruation of Health, in Men, Women, and Children, STC 4042 (London: Valentine Sims, 1595), D5r.

18. As the Revels editors point out, this anecdote is told of More's main opponent, Thomas Cromwell, in Fox's Acts and monuments (Munday, p. 9). Giving the anecdote back 
to More, as it were, adds to Hand C's flattering depiction of his subject and, notably, the anecdote is framed in terms of food, which is not present in Fox's version (Munday, Appendix D).

19. Annotating "housekeeping," the Revels editors emphasize More only as a generous host and patron (OED housekeeping n. 2. a.), ignoring the word's other meaning: "the maintenance of a household; the management of household affairs" (OED housekeeping $n$. 1.), which might be suggested by Doll but is most clearly what the Porter is getting at (Munday, pp. 99n63; 190n15).

20. Thomas Cogan, The Hauen of Health. Chiefely Gathered for the Comfort of Students, and Consequently of All Those That Have a Care of Their Health, Amplified Upon Five Words of Hippocrates, Written Epid. 6. Labor, Cibus, Potio, Somnus, Venus. Hereunto is Added a Preseruation from the Pestilence, with a Short Censure of the Late Sicknes at Oxford., sTC 5484 (London: Anne Griffin for Roger Ball, 1636), R3v.

21. Philip Moore, The Hope of Health Wherin is Conteined a Goodlie Regimente of Life: as Medicine, Good Diet and the Goodlie Vertues of Sonderie Herbes, STC 18059.5 (London: Ihon Kingston, 1564), $\mathrm{C}_{7} \mathrm{v}$.

22. Munday, p. 8.

23. Nicholas Harpsfield, The Life and Death of Sr Thomas Moore, Knight, Sometimes Lord High Chancellor of England, ed. Elsie Vaughan Hitchcock, Early English Text Society (London: Oxford University Press, 1932), p. 56.

24. Harpsfield, p. 19. The square brackets in this quotation are reproduced from Hitchcock's edition based on her collation of the eight manuscripts of Harpsfield's Life of More.

25. Harpsfield, p. 65 .

26. Harpsfield, p. 142 .

27. Boorde, D2v.

28. Andrew Boorde claimed that if beef is well salted, in order to get rid of thick blood, "it doth make an Englysshe man stronge the educacyon of him with it consydered" (Boorde, F1v-F2r), presumably meaning that it was best consumed by the non-intellectual. William Bullein noted that it is a meat that should be consumed by those engaged in manual labour and that "Much béefe customably eaten of idle persons, and nice folkes that labour not, bringeth many diseases ..." (Bullein, The Gouernment of Health: a Treatise ... for the Especiall Good and Healthfull Preseruation of Mans Bodie from All Noysome Diseases, Proceeding By the Excesse of Euill Diet, and Other Infirmities of Nature: Full of Excellent Medicines, and Wise Counsels, for Conseruation of Health, in Men, Women, and Children, I4v), but even here the warning is specifically against consuming too much beef.

29. Janet Adelman, Suffocating Mothers: Fantasies of Maternal Origin in Shakespeare's Plays, Hamlet to The Tempest (New York: Routledge, 1992), p. 149.

30. Harpsfield, p. 59 .

31. Harpsfield, pp. 59-61.

32. See Bullein. 
33. E. M.W. Tillyard, The Elizabethan World Picture (London: Chatto and Windus, 1943), pp. $87-91$.

34. John Bowle, Henry VIII: A Biography (London: George Allen and Unwin, 1964), p. 160 .

35. Stanley Cavell, “'Who Does the Wolf Love':? Coriolanus and the Interpretations of Politics," in Shakespeare and the Question of Theory, ed. Patricia Parker and Geoffrey Hartman (New York: Methuen, 1985), p. 249.

36. Munday, p. 238.

37. Harpsfield, pp. 95-96.

38. Harpsfield, p. 98.

39. Bullein, $\mathrm{F}_{2} \mathrm{v}-\mathrm{F}_{3} \mathrm{r}$.

40. Boorde, IAir.

41. Bowle, p. 160.

42. William Smith, ed., Dictionary of Greek and Roman Biography and Mythology, vol. 2: Earinus-NYX, 3 vols. (London: Walton and Maberly, 1865), p. 34.

43. Harpsfield, pp. 174-75.

44. Stanley Wells et al., eds., William Shakespeare: The Complete Works, 2nd ed. (Oxford: Clarendon Press, 2005).

45. James Wood, The Broken Estate: Essays on Literature and Belief (New York: Random House, 1999), p. 3.

46. Fred Zinnemann, A Man for All Seasons, Motion Picture. Columbia Pictures, 1966.

47. Celeste Turner, Anthony Munday: An Elizabethan Man of Letters (Berkeley: University of California Press, 1928), appendix 10; Hamilton, p. 203.

48. Oswald Gabelkover, The Boock of Physicke ... Translated Out of High-duche By the Right Worshipfull Mr. Doctour Charles Battus ... And Now Nuelye Translatede Out of Low-duche Into Englishe By A[nthony] M[unday], sTC 11513 (Dorte: Isaack Caen, 1599), Q5v-R2v.

49. Hamilton, p. xvii.

50. Scott McMillin, The Elizabethan Theatre and The Book of Sir Thomas More (Ithaca: Cornell University Press, 1987). 